THE KURUME MEDICAL JOURNAL Vol. 4, No. 2, 1957

\title{
PRESERVATION OF MYC. LEPRAEMURIUM BY MEANS OF LYOPHILIZATION II REPORT
}

\author{
YOH NAKAGAWA AND MASAHIRO NAKAMURA \\ Department of Microbiology, Kurume University School of Medicine, \\ Kurume-shi, Japan
}

A part of the serial experiments on the preservation of Myc. lepraemurium by means of lyophilization was reported in previous paper (1). The results obtained demonstrated that the infectious activity of Mycobacterium lepraemurium was still evi= dent after two years and five months over of the preservation in vitro by lyophilization, and that this period of maintenance of infectious activity of the bacilli was longer than that of the data reported by Shitama (2) and Lew (3).

In the present paper, an additional experiment on the infectious activity of the bacilli which were preserved for five years and five months over in the form of lyoplilization is reported.

\section{MATERIALS AND METHODS}

Bacterial strain and procedure in general was described in the previous report (1). Each lyophilized ample which was storaged in the refrigerator for five years and five months over was opened, and added one $\mathrm{ml}$ of distilled water. $0.5 \mathrm{ml}$ of each resuspended material was inoculated subcutaneously at the groin site of normal rats, these rats were killed after 170 days of inoculation of the materials, and leprosy changes at the site of inoculation and in the organs and glands of the inoculated rats were bacteriologically and histologically examined. Furthermore, the forms and staining properties of the bacilli were observed promptly after resuspension, by Ziehl-Neelsen staining and the electron micrographs.

\section{RESULTS}

Conditions of lyophilization. The conditions of dried and melted bacterial suspensions in the case of four different solutions, and stainable properties of the bacilli after dissolution are summerized in Table 1 .

The finding of the lyophilization in the case of the saline solution and serum water were pulverulently, while in the case of Kirchner's medium was somewhat moist, and of glycerine water was like as wheat-gluten, that is, remained moist. When these dried materials were resuspended in distilled water, however, homogeneous suspensions were 
obtained. The forms and staining properties of the bacilli in the resuspended tubes were a few differences indicated in Table 1, among four kinds of the solution. The properties of the bacilli were sustained as similarly as the original bacterial form, and were ungranuleous, straight, and good stainable, however, the stainability of the bacilli in the case of glycerine solution was somewhat weaker than that of the original. The findings under electron microscope were also very likely as that under light microscope mentioned above. However, as observed in photo 4, a change of the bacterial cell suggesting that autolysis of the bacterial surface occurred, was recognized in the case of glycerine water.

TABLE 1

The relationship between conditions of lyophilization ant properties of the bacilli

\begin{tabular}{|c|c|c|c|c|}
\hline Medium & $\begin{array}{l}\text { Time of } \\
\text { hour of } \\
\text { lyophili- } \\
\text { zation }\end{array}$ & $\begin{array}{l}\text { Drying } \\
\text { condition }\end{array}$ & $\begin{array}{l}\text { Dissolu- } \\
\text { tion }\end{array}$ & Staining quality \\
\hline Saline solution & 2 & pulverulent & $\begin{array}{l}\text { homo- } \\
\text { geneous }\end{array}$ & $\begin{array}{l}\text { Good, ungranuleoes but with a few } \\
\text { big brown bodies, typical form }\end{array}$ \\
\hline $10 \%$ Serum water & 2 & pulverulent & $\begin{array}{l}\text { homo- } \\
\text { geneous }\end{array}$ & $\begin{array}{l}\text { typical form with good stainable } \\
\text { properties }\end{array}$ \\
\hline $4 \%$ Glycerine water & 3 & $\begin{array}{l}\text { wheat-gluten } \\
\text { like }\end{array}$ & $\begin{array}{l}\text { homo- } \\
\text { geneous }\end{array}$ & $\begin{array}{l}\text { typical form with bad stainable } \\
\text { properties }\end{array}$ \\
\hline $\begin{array}{l}\text { Kirchner's medium } \\
\text { containing } 10 \% \text { serum }\end{array}$ & 3 & $\begin{array}{l}\text { somewhat } \\
\text { moist }\end{array}$ & $\begin{array}{l}\text { homo- } \\
\text { geneous }\end{array}$ & $\begin{array}{l}\text { Good, with a few big brown } \\
\text { granules }\end{array}$ \\
\hline
\end{tabular}

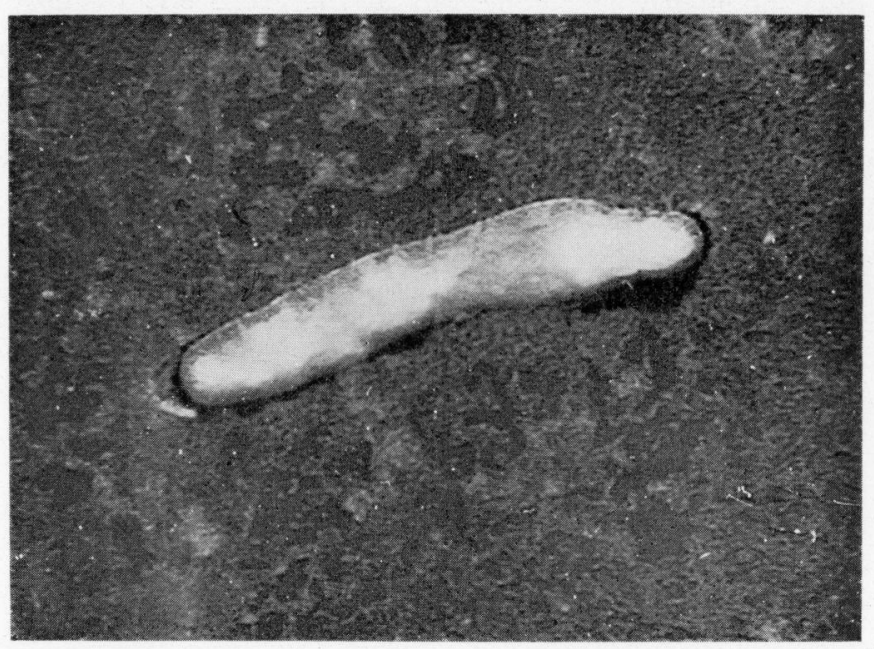

Photo 1. Myc. lepraemurium suspended in the saline solution. 


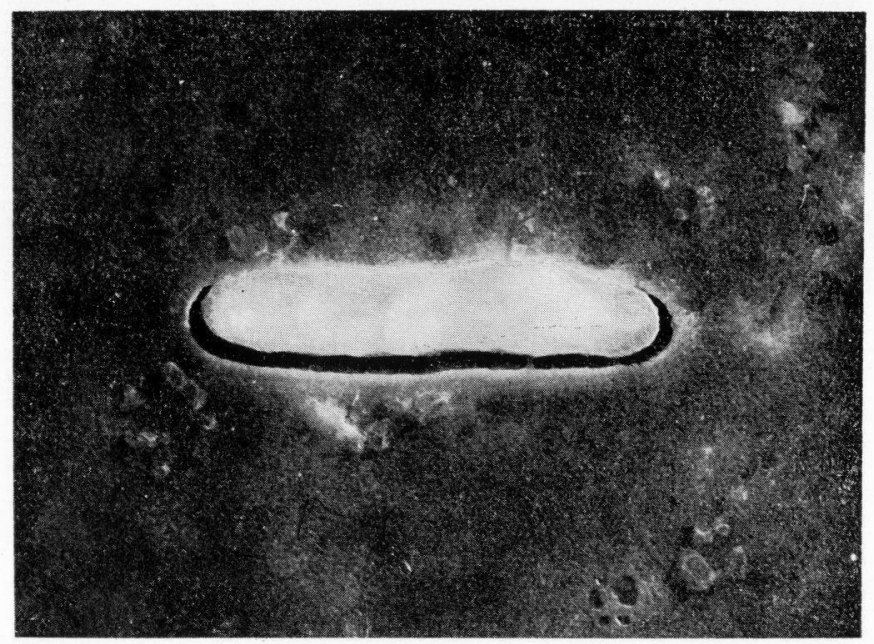

Photo 2. Myc. lepraemurium suspended in the serum water.

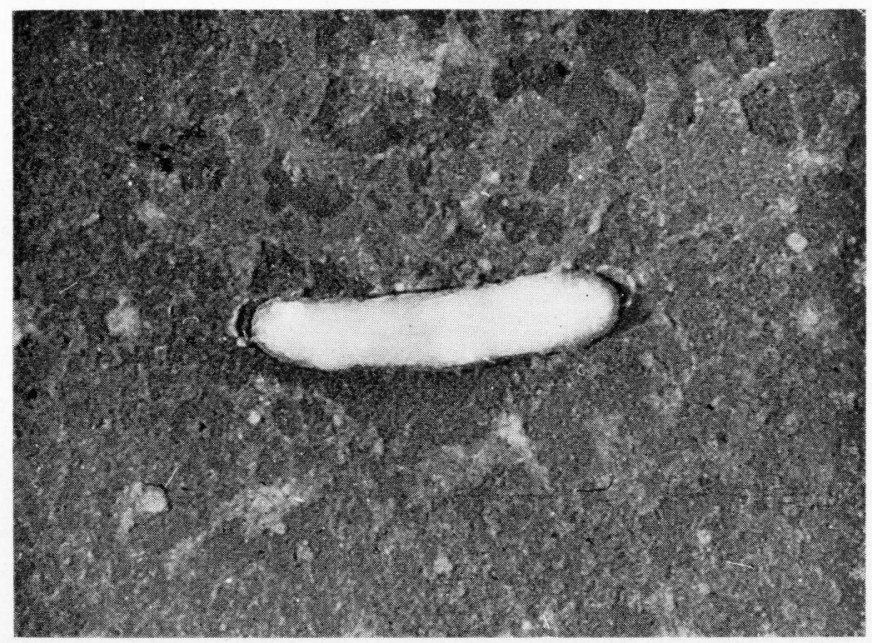

Photo 3. Myc. lepraemurium suspended in Kirchner medium. 


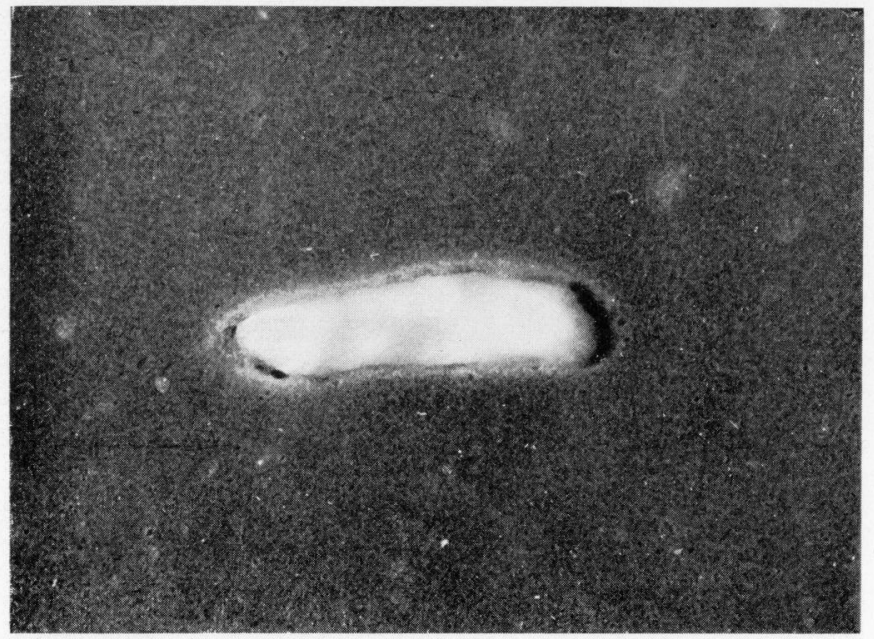

Photo 4. Myc. lepraemurium suspended in the glycerine water.

TABLE 2

Determination of infectious activity of lyophilized bacilli by animal experiments

\begin{tabular}{|c|c|c|c|c|c|c|c|c|c|c|}
\hline \multirow{2}{*}{$\begin{array}{l}\text { Time of } \\
\text { storage } \\
\text { at } 4 \mathrm{C}\end{array}$} & \multirow{2}{*}{$\begin{array}{l}\text { Date of } \\
\text { inocul. } \\
\text { into } \\
\text { rats }\end{array}$} & \multirow{2}{*}{ Medium } & \multirow{2}{*}{ 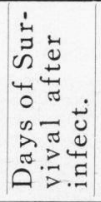 } & \multirow{2}{*}{ 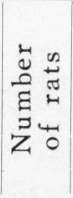 } & \multicolumn{5}{|c|}{$\begin{array}{l}\text { Bacteriological and histological } \\
\text { results in infected rats }\end{array}$} & \multirow{2}{*}{ 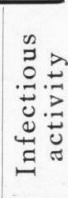 } \\
\hline & & & & & $\begin{array}{l}\text { Site of } \\
\text { inocula- } \\
\text { tion }\end{array}$ & $\begin{array}{l}\text { Groinal } \\
\text { gland }\end{array}$ & $\begin{array}{l}\text { Iliac } \\
\text { gland }\end{array}$ & $\begin{array}{l}\text { Axillary } \\
\text { gland }\end{array}$ & Organs & \\
\hline \multirow{4}{*}{$\begin{array}{l}5 \mathrm{yrs}, \\
5 \mathrm{~ms} \text {, } \\
\text { and } \\
5 \text { days }\end{array}$} & \multirow{4}{*}{$\begin{array}{c}1, \text { Oct., } \\
1956\end{array}$} & Saline & 171 & 3 & $\begin{array}{l}-(-) \\
\text { Ht }(\infty) \\
+(+)\end{array}$ & $\begin{array}{c}000(H H) \\
000(H H) \\
00(\infty)\end{array}$ & $\begin{array}{c}\circ(-) \\
\circ \circ(t) \\
\circ(t)\end{array}$ & $\begin{array}{r}\circ(-) \\
o(+) \\
0 \circ 0(t)\end{array}$ & $\begin{array}{l}(-) \\
(-) \\
(-)\end{array}$ & + \\
\hline & & $\begin{array}{c}\text { Glycerine } \\
\text { water }\end{array}$ & 170 & 2 & $\begin{array}{l}-(-) \\
+\quad(-)\end{array}$ & $\begin{array}{l}o(-) \\
o(-)\end{array}$ & $\begin{array}{l}\circ(-) \\
\circ(-)\end{array}$ & $\begin{array}{l}0 \circ(-) \\
0 \circ(-)\end{array}$ & $\begin{array}{l}(-) \\
(-)\end{array}$ & - \\
\hline & & $\begin{array}{l}\text { Serum } \\
\text { water }\end{array}$ & $\begin{array}{l}141 \\
170\end{array}$ & 2 & $\begin{array}{l}+(H H) \\
H H(H H)\end{array}$ & $\begin{array}{l}\text { oo }(t) \\
\text { oo }(\mathrm{HH})\end{array}$ & $\begin{array}{l}o(+) \\
o(-)\end{array}$ & $\begin{array}{l}\circ \circ(-) \\
\circ \circ(-)\end{array}$ & $\begin{array}{l}(-) \\
(-)\end{array}$ & + \\
\hline & & $\begin{array}{l}\text { Kirchner's } \\
\text { medium }\end{array}$ & 170 & 3 & $\begin{array}{l}-(+) \\
H+(\infty) \\
-(-)\end{array}$ & $\begin{array}{r}o(t t) \\
\circ \circ(t) \\
o(t+)\end{array}$ & $\begin{array}{l}\circ(-) \\
\circ(-) \\
\circ(-)\end{array}$ & $\begin{array}{l}00(-) \\
00(t) \\
0 \circ(t)\end{array}$ & $\begin{array}{l}(-) \\
(-) \\
(-)\end{array}$ & + \\
\hline
\end{tabular}


Animal experiments. The leprosy infiltration was produced at the site of inoculation of the materials in the saline, serum, and Kirchner's solution, or even if the infiltration had not been recognized, the great amount of the bacilli and the leprosy cells which produced by the bacilli were observed in the stained preparation of the regional grands. On the contrary, the leprosy changes at the site of inoculation of the material in the glycerine water were not determined, though the leprosy like infiltration was found in one case of the rats tested. These results were shown in Table 2.

It is obvious, therefore, that the infectious activities of the bacilli lyophilized in the suspensions with saline solution, serum water, and Kirchner's medium still remained after five years and five months of the storage in vitro, while the activity of the bacilli in the case of the suspension with the glycerine water was already lost.

\section{DISCUSSION}

As discussed in the previous report (1), the research on the preservation of Mycobacterium lepraemurium in vitro, for example by means of lyophilization, might be very important and significant, in order to learn if the bacilli could be preserved in vitro for a long period or not since the cultivation method of the bacilli has not yet been succeeded and then they have been maintained only by inoculating into rats or mice up to the present day, and in order to study an approach to the clarification of the biological and chemical properties of the bacilli concerning the activity under various influences of drying and freezing. Yaoi, Tagaya, and Yoshino (4) reported that the activity of $\mathrm{H}$. pertussis I-phase suspended in water containing $50 \%$ inactivated serum by means of lyophilization was maintained for a year and four months, and that, the kinds of the suspended media influenced on the activity of the bacilli during preservation in vitro by drying and freezing. Pirtle (5) reported also, that the ability of Dipl. pneumoniae "Type 1 to produce capsules and its virulence for mice decrease rapidly when a virulent culture is serially transferred in blood medium or when lyophilized, and then the infected mice were putted into 200 by $25 \mathrm{~mm}$ Pyrex tubes which were fitted with rubber stoppers, and placed at-20 C. The fact that the numbers of viable bacilli of BCG decrease for the presevation by lyoplilization is very known. It may be presumed, therefore, that the metabolism of the bacilli has continued at low grade even during drying and freezing of the bacilli. Though it may be thought that the stability of Myc. lepraemurium is not as labile as that of $\mathrm{H}$. pertussis I. phase and Dipl pneumoniae, it will be not able to declare that a sort of the medium in which Myc. lepraemurium is suspended does not influence upon the activity of the bacilli during presevation for a long period.

In this paper, the data obtained demonstrate that the saline solution is most suitable 
for maintenace of the infectious activity of the bacilli by lyoplilization among the solutions tested which suspended the material, and that the activity of the bacilli in the case of glycerine water has lost. In the previous report on the preservation of the bacilli for 2 years and five months also, an analogous tendancy was observed, that is, the infectious ability of the bacilli in the glycerine water was worst, and the proof of the infectious activity of the bacilli was barely determined after the inoculation to the second generation into rats. The factors that influenced on the activity of the bacilli seems to be attributed to lack of dryness of the solution suspended the materials during storage.

It may be not decided at present whether the change of the bacterial form in the glycerine water observed by electron microscope is connected with the activity of the bacilli or not.

\section{SUMMARY}

Myc. lepraemurium lyoplilized in the saline solution, serum water, Kirchner's medium, and glycerine water were storaged in a refrigerator for about five years and five months and then the infectious activity of the bacilli were determined by inoculation of the materials into normal white rats. The results obtained indicated that the infectious activity of the bacilli in these solutions with the exception of glycerine water had still maintained.

\section{REFERENCES}

1. Nakagawa, Y. and Nakamura, M.: Preservation of Myc. lepraemurium by means of lyophilization I. Report. Kurume Med.'J., Vol. 1, 135-139, 1954.

2. Shitama, K.: Preservation of bacterial strains by means of lyophilization. Jap. Zeisschrift für Mikrobiologie und Pathologie Vol. 37, 475-508, 1943, (in Japanese).

3. LEw, S.: Experimental studies of leprosy. Acta. Medica, Vol. 20, 991-1008, 1951 (in Japanese).

4. Yaoi, H., Tagaya, I., and Yoshino, K.: Studies on the preservation of H. Pertussis. Jap. J. Bact., Vol. 5, 39-42, 1950 (in Japanese).

5. Pirtle, E. C.: Preservation of Diplococcus pneumoniae. J. Bact., Vol. 71, 498-499, 1956. 